\title{
Roles of Lipids in the Permeability Barriers of Skin and Oral Mucosa
}

\author{
Philip W. Wertz (1)
}

check for

updates

Citation: Wertz, P.W. Roles of Lipids in the Permeability Barriers of Skin and Oral Mucosa. Int. J. Mol. Sci. 2021, 22, 5229. https://doi.org/ 10.3390/ijms22105229

Academic Editor: Magnus S. Ågren

Received: 23 April 2021

Accepted: 10 May 2021

Published: 15 May 2021

Publisher's Note: MDPI stays neutral with regard to jurisdictional claims in published maps and institutional affiliations.

Copyright: (C) 2021 by the author. Licensee MDPI, Basel, Switzerland. This article is an open access article distributed under the terms and conditions of the Creative Commons Attribution (CC BY) license (https:// creativecommons.org/licenses/by/ $4.0 /)$.
University of Iowa, Iowa City, IA 52242, USA; philip-wertz@uiowa.edu; Tel.: +1-319-337-4364

\begin{abstract}
PubMed searches reveal much literature regarding lipids in barrier function of skin and less literature on lipids in barrier function of the oral mucosa. In terrestrial mammals, birds, and reptiles, the skin's permeability barrier is provided by ceramides, fatty acids, and cholesterol in the outermost layers of the epidermis, the stratum corneum. This layer consists of about 10-20 layers of cornified cells embedded in a lipid matrix. It effectively prevents loss of water and electrolytes from the underlying tissue, and it limits the penetration of potentially harmful substances from the environment. In the oral cavity, the regions of the gingiva and hard palate are covered by keratinized epithelia that much resemble the epidermis. The oral stratum corneum contains a lipid mixture similar to that in the epidermal stratum corneum but in lower amounts and is accordingly more permeable. The superficial regions of the nonkeratinized oral epithelia also provide a permeability barrier. These epithelial regions do contain ceramides, cholesterol, and free fatty acids, which may underlie barrier function. The oral epithelial permeability barriers primarily protect the underlying tissue by preventing the penetration of potentially toxic substances, including microbial products. Transdermal drug delivery, buccal absorption, and lipid-related disease are discussed.
\end{abstract}

Keywords: barrier function; ceramides; cholesterol; fatty acids; intercellular lamellae; keratinocytes; oral mucosa; skin

\section{Introduction}

Several reviews of various aspects of the roles of lipids in the barrier function of the skin have been published recently [1-4]. Major points will be summarized here, but the readers are referred to these previous reviews for more detail.

The surface of an average human skin is approximately two square meters in area and serves as our interface with the environment. It serves to prevent loss of water and electrolytes. It also effectively prevents the penetration of a range of potentially harmful chemicals from the environment, including microbial products. The evolution of life on dry land required the development of watertight skin [5]. The permeability barrier of the skin is provided by the outermost layer, the stratum corneum [6]. Specifically, an approximately equimolar mixture of ceramides, fatty acids, and cholesterol between the flattened, cornified cells determine the permeability of the skin [7].

The situation in the oral cavity has some similarities to the skin, but there are also some distinct differences. The oral mucosa is coated with saliva, so there is no water gradient. Therefore, there is no driving force for water loss through the mucosa. Nevertheless, there is a need for a barrier sufficient to prevent the penetration of potentially harmful substances from food, beverages, and microorganisms. Lipids appear to play some role in the oral mucosal barriers; however, this has been much less studied than the barrier lipids of the skin. Removal of lipids from buccal mucosa resulted in a marked increase in permeability, suggesting a role for lipids in barrier function of nonkeratinized oral epithelia [8]. Much of the works on the oral mucosal barriers have been directed at the delivery of drugs by absorption through the mucosa of the mouth [9].

In the barriers of both skin and oral mucosa, substances that penetrate the barrier do so by passive diffusion $[10,11]$. The primary pathway through which compounds diffuse 
through these permeability barriers is paracellular $[12,13]$. Sebaceous follicles of the skin have been shown to serve as a shunt pathway [14]. Although there are sebaceous glands, sometimes called Fordyce granules, throughout the oral mucosa their significance in drug uptake is uncertain $[15,16]$. Likewise, sweat ducts and salivary ducts are potentially minor, and relatively unexplored, potential routes by which substances could cross the skin or mucosa, respectively.

\section{Skin}

Nicolaides identified ceramide as a skin lipid in 1965 based on an infrared spectrum of polar material recovered from the origin of a thin-layer chromatographic plate [17].

The work of G.M. Gray and associates in the mid to late 1960s established ceramides as major lipids of the permeability barrier [18]. This group established that the lipid composition of epidermal keratinocytes alters dramatically as a function of differentiation [19]. The basal and spinous cells contained mostly phosphoglycerides and sphingomyelin with a small amount of cholesterol. As differentiation proceeds, the amount of lipid increases with the amounts per cell of both phospholipids and cholesterol increasing, but glucosylceramides also accumulate. Near the boundary of the granular layer and the stratum corneum phospholipids are broken down. Fatty acids are released from the phosphoglycerides, and ceramides are released from sphingomyelin. Glucosylceramides are deglycosylated to produce ceramides. Ceramides, fatty acids, and cholesterol are the main lipids in the stratum corneum. The fatty acids in the stratum corneum are mainly saturated, range from 14 through 28 carbons in length, and the most abundant are C22:0 and C24:0 [20].

It was established that the glucosylceramides and ceramides are structurally heterogeneous [18]. Although individual ceramide structures were not elucidated, most of the building block fatty acids and long-chain bases were identified. The fatty acids included normal and $\alpha$-hydroxyacids both ranging between 14- and 30-carbons in length. The 24and 26-carbon saturated normal and $\alpha$-hydroxyacids were prominent. The long-chain bases were from 16- through 22-carbons in length, and included sphingosines, dihydrosphingosines, and phytosphingosines. The major species identified were 18-carbon entities, and some unidentified entities were noted.

The most abundant and least polar of the glucosylceramides was isolated, and the structure was partially identified [21]. The $\beta$-glycosidically attached glucose was identified by proton magnetic resonance of the intact molecule and by gas-liquid chromatography of the trimethylsilalated isolated sugar. The major ester-linked fatty acid was identified as an 18-carbon diene, probably linoleic acid by gas-liquid chromatography of the methyl esters. It constituted $77.4 \%$ (pig) to $56.2 \%$ (human) of the total fatty acids. The long-chain bases were shown to consist of a mixture of sphingosines and dihydrosphingosines by gas-liquid chromatography of the trimethylsilated derivatives. However, the ester-linked fatty acids were said to be mainly attached to the 3-hydroxyl group of the glucose, and based on electron impact mass spectral data, the amide-linked fatty acid was said to be 35-carbons long with two double bonds and two hydroxyl groups between carbon-16 and carbon-20. These latter two features subsequently proved to be incorrect. The amide-linked fatty acid was subsequently identified as a series of mostly 30-through 34-carbon $\omega$-hydroxyacids, and the identity of the 18-carbon diene as linoleic acid was confirmed [22]. The esterlinked fatty acid was found to be attached to the $\omega$-hydroxyl group of the amide-linked hydroxyacid [23,24].

During the 1980s the structures of the glucosylceramides and ceramides from pig epidermis were published $[25,26]$. The ceramides included an $\omega$-O-acylceramide analogous to the acylglucosylceramide $[24,26]$. Isolated epidermal lamellar granules were shown to be enriched in glucosylceramides, including the linoleate-containing acylglucosylceramide $[27,28]$. Acylglucosylceramide in the bounding membrane of the lamellar granules is the precursor of the $\omega$-hydroxyceramides that become attached to the outer surface of the cornified envelope, thereby forming the corneocyte lipid envelope (CLE) $[4,29,30]$. Acylglucosylceramide within the internal lamellae of the lamellar granule becomes degly- 
cosylated to form the acylceramide that passes into the intercellular spaces of the stratum corneum [24,26]. This is illustrated in Figure 1.

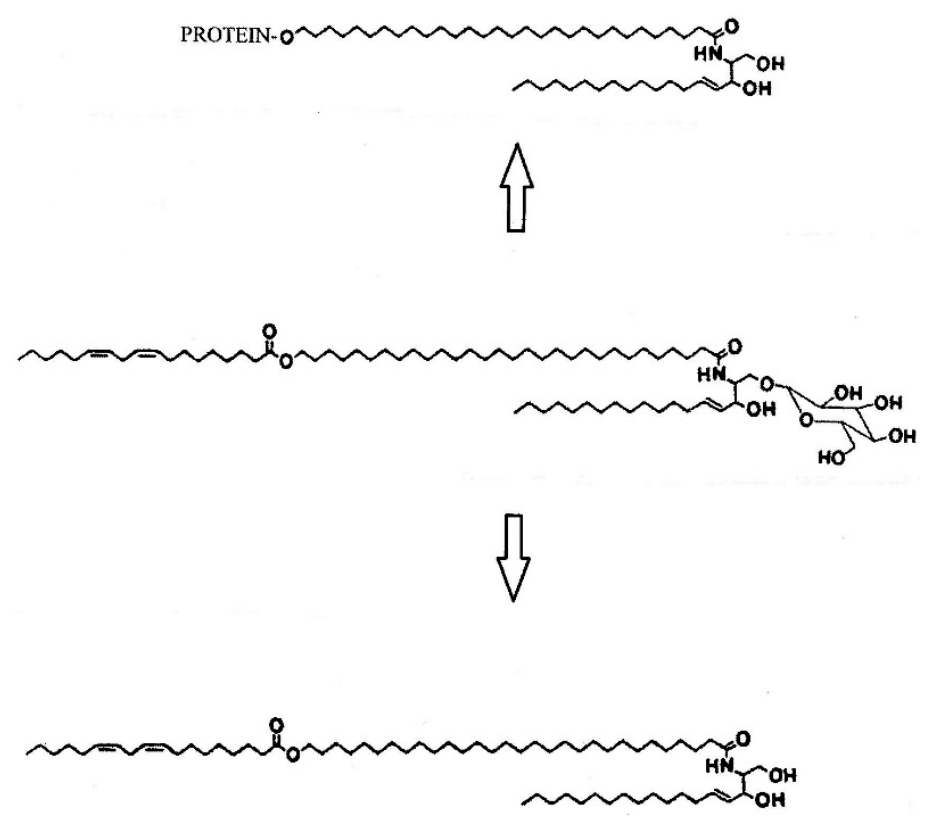

Figure 1. The linoleate-rich acylglucosylceramide (center) is the precursor of the linoleate-rich acylceramide (bottom) found in the intercellular spaces of the stratum corneum and the covalently bound $\omega$-hydroxyceramide (top), or CLE.

Transmission electron microscopy with ruthenium tetroxide post-fixation revealed multilamellar structures within the intercellular spaces of the stratum corneum [31]. Multiple trilamellar repeat units, each of which, had a $13 \mathrm{~nm}$ overall dimension were evident. This same $13 \mathrm{~nm}$ repeat unit was found by X-ray diffraction, and it was shown that the linoleate-containing acylceramide was required for the formation of this $13 \mathrm{~nm}$ trilamellar structure [32-34].

Both X-ray diffraction and electron diffraction reveal that the lateral packing of lipids in healthy stratum corneum is predominantly orthorhombic [35-38]. Upon heating, there is a shift from orthorhombic lateral packing to hexagonal packing. Moreover, in atopic dermatitis and lamellar ichthyosis, where barrier function is impaired, hexagonal packing is increased relative to orthorhombic packing [39]. In lamellar ichthyosis, hexagonal packing predominates.

Lamellar granules bud off from a tubuloreticular membrane system in the outermost granular cells [40]. At the boundary between the granular layer and the stratum corneum, the bounding membrane of the lamellar granule fuses into the cell plasma membrane, and the contents of the granule are extruded into the intercellular space [41]. At this time, glucocerebrosidase converts glucosylceramide to ceramides, and acid sphingomyelinase converts sphingomyelin to ceramide [42,43]. Fatty acids are released from phosphoglycerides $[44,45]$. This lipid remodeling is accompanied by fusion of the short lamellae to form broad multilamellar sheets [46], shown in Figure 2. Acylglucosylceramide from the lamellar granule gives rise to the CLE and the acylceramide among the free lipids in the stratum corneum. Together, the CLE and intercellular lipid lamellae determine the permeability of the skin. The structures of human stratum corneum-free ceramides are shown in Figure 3. 


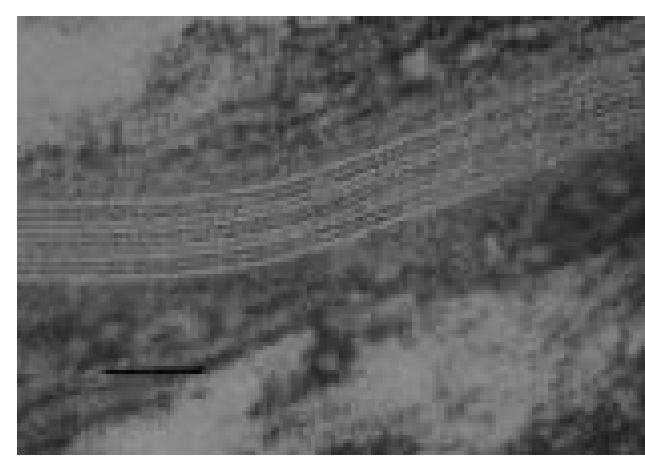

Figure 2. Transmission electron micrograph of $\mathrm{RuO}_{4}$-fixed human stratum corneum showing intercellular lamellae between two corneocytes (SC). The first lucent band on either side of the intercellular space is the CLE. Bar $=50 \mathrm{~nm}$.

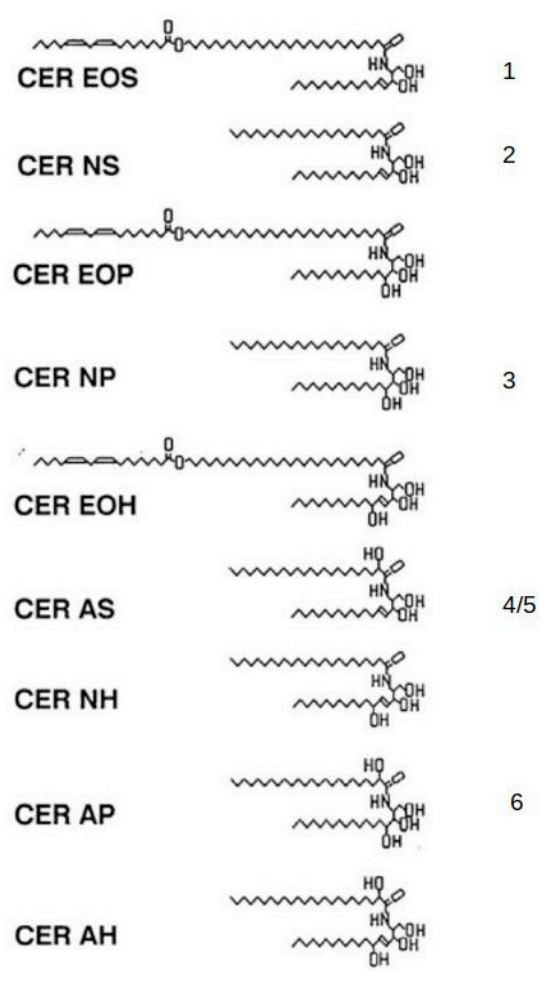

Figure 3. Structures of ceramides from human stratum corneum [47]. In the nomenclature on the left $\mathrm{S}, \mathrm{P}$, and $\mathrm{H}$ indicate sphingosine, phytosphingosine and 6-hydroxysphingosine, and $\mathrm{N}, \mathrm{A}$, and $\mathrm{O}$ indicate normal fatty acid, $\alpha$-hydroxyacid and $\omega$-hydroxyacid. E indicates the presence of an esterlinked fatty acid [48]. In these structures, sphingosine is always accompanied by dihydrosphingosine. The numbers on the right indicate the ceramides found in the porcine stratum corneum [26]. In this case, CER AS (4/5) separates into two fractions on thin-layer chromatography. Fraction 4 contained mainly C24-C28 $\alpha$-hydroxyacids, while fraction 5 contained $\alpha$-hydroxypalmitic acid as the sole amide-linked fatty acid.

\section{Keratinized Oral Mucosa}

All regions of the oral mucosa are covered by a stratified squamous epithelium; however, the pattern of differentiation varies regionally [49]. The gingiva and hard palate are covered by a keratinizing epithelium similar to the epidermis of the skin. The floor of the mouth, buccal regions, and the underside of the tongue are covered by a nonkeratinized epithelium. The specialized epithelium on the dorsum of the tongue is approximated as a mosaic of keratinized and nonkeratinized epithelia. 
In the keratinized oral epithelia, lipids are packaged in lamellar granules just as in the epidermis $[50,51]$. However, the volume density of lamellar granules in the keratinizing oral epithelia is less than in the epidermis [52]. Accordingly, the lipid content of the oral stratum corneum is less than that in the epidermal stratum corneum [53]. The stratum corneum from the gingiva and hard palate contain ceramides, cholesterol, and fatty acids, but they also contain small amounts of phospholipids that are not found in the epidermal stratum corneum The ceramide profile of the oral stratum corneum was similar to that of the epidermal stratum corneum. A more detailed analysis of the ceramides from the porcine palatal stratum corneum revealed that the structures were almost identical to the structures determined for porcine epidermal ceramides shown in Figure 2 [54]. The one exception was that while linoleate is the major (71.7\%) ester-linked fatty acid in epidermal ceramide EOS, in the palatal ceramide EOS linoleate is only $8.8 \%$ of the ester-linked fatty acids. The other ester-linked fatty acids were C16:0, C18:0, C20:0, and C18:1. Linoleaterich ceramide EOS is thought to be essential for the formation of the 13-nm trilamellar repeat units in the epidermal stratum corneum intercellular lipids [33,55,56]. In Figure 1, there are nine lucent bands in the intercellular space, and these bands appear to alternate broad-narrow-broad in width. Each of these trilayers represents one $13 \mathrm{~nm}$ repeat unit. The modified ceramide EOS found in the keratinized oral epithelium does not support the formation of these trilamellar structures [57]. Paired bilayers and sometimes swirls of lamellae are seen in electron micrographs.

The fatty acid composition of the palatal ceramide EOS has implications for the CLE. In the epidermis, the precursor to ceramide EOS is a glucosylceramide, and both have identical fatty acid compositions dominated by linoleic acid. The epidermal acylglucosylceramide is the precursor for both the acylceramide and the CLE. The palatal linoleate-poor ceramide EOS does not support the formation of the $13 \mathrm{~nm}$ trilamellar units, and its precursor does not support the formation of the corneocyte lipid envelope [58].

Because the oral stratum corneum contains less lipid than the epidermal stratum corneum, and because the lipid in the oral tissue is less orderly organized, it would be expected that the permeability of the keratinized oral regions would be greater than that of skin. This is the case [59]. The permeability coefficient for tritiated water, Kp, was approximately ten times higher for palatal tissue compared to skin.

\section{Nonkeratinized Oral Mucosa}

The nonkeratinizing oral mucosal regions do not have an anatomically distinct barrier. In the keratinizing epithelia, the internal organelles are degraded during differentiation, and the plasma membrane becomes replaced by a thick band of olymerized protein. In the nonkeratinizing regions, the internal organelles and plasma membrane are retained. This makes it difficult to study roles for lipids in the barrier function of these regions. The superficial layers of these nonkeratinized epithelia can be isolated by tryptic digestion, and the lipids can be extracted and analyzed [53]. However, most of the lipid so obtained comes from the plasma membrane and residual internal organelles. It is not possible to determine which lipids are involved in barrier function from the analysis of such extracts. However, there is some ceramide (CER NP), and abundant cholesterol and free fatty acids are present. This suggests the possibility that there may be a barrier somewhat resembling that found in the keratinizing epithelia.

The epithelium from the floor of the mouth is, on average, $192 \mu \mathrm{m}$ thick, while the buccal epithelium is $772 \mu \mathrm{m}$ thick [60]. When horseradish peroxidase or lanthanum were used to follow the movement of water through these tissues it was observed that neither agent could penetrate from the surface of the tissue; however, both could freely penetrate between the cells when introduced from the underside of the tissue. Progress of these penetrants halted at approximately two-thirds of the way from the bottom to the surface [60-62]. Thus, it appears that this superficial outer third of the epithelium represents the permeability barrier. This localization corresponds to the location at which "membranecoating granules" discharge their contents $[50,63]$. These membrane-coating granules are 
of about the same size as the lamellar granules seen in the epidermis and keratinized oral epithelia; however, instead of lamellar material, the granules contain an electron-dense core with electron-dense filaments extending toward the bounding membrane. The chemical nature of this material is unknown. In 1995, a second secretory vesicle of similar size to the cored granules was reported [53]. This secretory granule was not apparent in transmission micrographs of samples prepared with conventional osmium tetroxide fixation. It was only seen in sections of specimens fixed with ruthenium tetroxide. These granules contained lamellar material and have been called lamellate granules. Their content is discharged near the bottom of the superficial layer of the epithelium and can be seen as short stacks of lamellae running diagonally across the intercellular space, as illustrated in Figure 4.

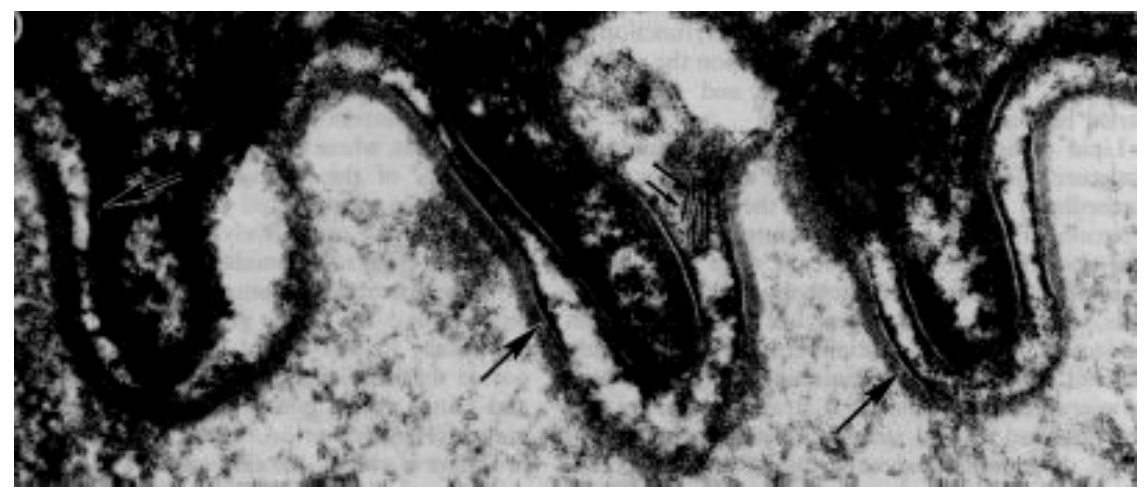

Figure 4. Transmission electron micrograph of RuO4-fixed superficial porcine epithelium from the floor of the mouth. The arrow indicates the plasma membrane. The double arrows indicate a stack of lamellae running transversely across the intercellular space. The magnification was $\times 100,000$. Reprinted with permission from ref. [53]. Copyright 1995 Elsevier.

\section{Transdermal Drug Delivery}

Most drugs are administered orally as pills or liquids or by injection. The transdermal route of drug delivery has several advantages over the oral and parenteral routes of drug delivery. The skin is readily accessible and avoids the acid environment of the stomach, the digestive enzymes of the gut, and first-pass metabolism in the liver. Unlike swallowing a pill or receiving an injection, transdermal drug delivery patches can deliver the drug over an extended period. This can maintain a relatively constant systemic concentration of the drug. Should one develop an adverse drug reaction, the patch can be removed. One disadvantage of the transdermal patch is that some individuals develop irritation at the site of patch placement. There are also limitations to the kinds of molecules that can be delivered through the skin [64]. Molecules with molecular weights (MW) greater than about 350 daltons do not penetrate well. Additionally, the polarity of the molecule must fall within a limited range. Polarity is quantitatively assessed as an oil-water or octanol-water partition coefficient. Generally, the LOG $\left(\mathrm{K}_{\text {octanol-water }}\right)$ must fall within the range of about 1 to 4 [64]. Table 1 lists several drugs that are delivered via transdermal patches. Compounds with lower octanol-water partition coefficients cannot partition into the intercellular lipids of the stratum corneum. Compounds with higher octanol-water partition coefficients can enter the stratum corneum but are too hydrophobic to enter the more aqueous environment of the viable epidermis. 
Table 1. Molecular weights (MW) and LOG ( $\left.\mathrm{K}_{\text {octanol-water }}\right)$ of several drugs that are delivered via transdermal patches. The data for this table were obtained from the National Library of Medicine through Pubchem (https:/ / pubchem.ncbi.nlm.nih.gov, (accessed on 19 March 2021)).

\begin{tabular}{ccc}
\hline Drug & MW & Log (K) \\
\hline nicotine & 162 & 1.2 \\
nitroglycerin & 227 & 1.6 \\
lidocaine & 234 & 2.3 \\
estradiol & 272 & 4.0 \\
testosterone & 288 & 3.3 \\
scopolamine & 303 & 1.0 \\
fentanyl & 336 & 4.1 \\
\hline
\end{tabular}

Many efforts have been made to enhance the flux of drugs through the stratum corneum [65]. A wide range of chemicals has been tested in this regard. Among the most widely used chemical permeability enhancers are ethanol, unsaturated fatty acids, surfactants, and terpenoids. Flexible liposomes prepared with phospholipids and surfactant were once thought to transport encapsulated drugs across the stratum corneum by squeezing through the intercellular spaces; however, it is now thought that the surfactant permeabilizes the intercellular lamellae to enhance drug flux [66]. There may also be increased hydration of the stratum corneum, which would increase permeability.

A variety of physical methods have also been used to increase drug flux across the stratum corneum. One of these methods is sonophoresis [67-69]. In this technique, low-frequency ultrasound increases the vibrational energy of the lipid molecules in the stratum corneum, thereby causing fluidization and increased permeability. This technique is capable of delivering macromolecules [70]. A disadvantage of this technique is that because of the required equipment its use is largely confined to hospitals.

Another technique that is used to increase skin permeability is iontophoresis [71]. In iontophoresis, a mild current is generated between a cathode and an electrode on the skin surface. Positively charged drugs, such as lidocaine hydrochloride, can be driven into the stratum corneum from a solution at the anode site. This electromigration is caused by electrostatic repulsion. Neutral molecules will flow with the current from anode to cathode by electro-osmosis. The apparatus for iontophoresis has been miniaturized to the size of a wristwatch [72]. The GlucoWatch Biographer (Cygnus Inc., Redwood City, CA, USA), brought to market in 2002, used electro-osmosis to sample glucose from interstitial fluid for diabetic monitoring [73]. Unfortunately, this device did not meet expectations and was taken off the market in 2007 [74]. The most common use of iontophoresis is the treatment of palmar or plantar hyperhidrosis [75]. This is frequently done with tap water so that hydrogen ions are delivered into the eccrine sweat glands, but sometimes anticholinergic agents are added.

Electroporation uses high voltage pulses to perturb the organization of the intercellular lipid lamellae of the stratum corneum [76]. Electroporation is a safe and effective method for cutaneous and subcutaneous delivery of bleomycin or cisplatin for the treatment of malignant melanoma or other malignancies [77].

Perhaps the most promising technology for bypassing the barrier of the stratum corneum is microneedles [78]. Microneedle array patches have been under development for several decades. Early difficulties with manufacturing methodology and properties of the product have finally been overcome, and at least eleven products are now on the market [79]. The microneedles are long enough to traverse the stratum corneum, which causes no pain. They can be solid, hollow, or dissolvable. Solid microneedles are coated with the active agent. while the active agent is pumped through the hollow microneedles. Dissolvable microneedles have the active agent incorporated into the needle which is usually a sugar or dissolvable protein or polymer [80]. The advent of 3D printing now facilitates the manufacturing process [81]. By physically and painlessly breaching the barrier, there are no restrictions on what can be delivered across the barrier. Nucleic acids, proteins such 
as insulin, and ionic materials can now cross the skin barrier. The skin is an attractive site for vaccination. Because of the Langerhans cells in the epidermis and the dendritic cells in the dermis, the skin would appear to be a better site for vaccination than muscle which lacks antigen-presenting cells [82,83]. This is supported by an animal experiment in which the results of microneedle array delivery of influenza vaccine to the skin were compared to intramuscular vaccination [84]. When compared to the intramuscular group, the microneedle group had more influenza-specific antibody-producing cells. In addition, there was increased activation of helper $\mathrm{T}$ cells and formation of germinal centers in regional lymph nodes.

\section{Skin Disease and the Barrier}

Poison ivy rash is classic allergic contact dermatitis and an occupational hazard for outdoor workers [85]. It is caused by a mixture of phenolic compounds known collectively as urushiol [86]. Urushiols consist of catechol (1,2-dihydroxybenzene) with a linear carbon chain attached to carbon 3 . The side chains all contain 15 carbon atoms, but they differ in the number (0-3) and location of double bonds. All have molecular weights in the range of 314-320 daltons. Although no published octanol-water partition coefficient could be found, these molecules readily cross the stratum corneum barrier.

Atopic dermatitis is a skin disease that, although it can occur at any age, usually presents in early childhood. It is characterized by dry, itchy, and easily irritated skin with fluctuating disease activity. Many atopic subjects also suffer from asthma. Transepidermal water loss is elevated indicating impaired barrier function [87]. It has long been known that stratum corneum lipids are altered in this condition [88-91]. In general, when comparing lipids from the atopic stratum corneum to the lipids from the normal control stratum corneum, the total amount of ceramide was reduced. The ceramide to cholesterol ratio was reduced, and some ceramide fractions were altered more than others. The linoleate containing ceramide EOS was significantly lower in the atopic stratum corneum, and oleate replaced some of the linoleate $[89,91]$. The reduced level of ceramides in atopic dermatitis is at least partly the result of an elevated enzyme activity that can hydrolyze the amide linkages in both sphingomyelin and glucosylceramide [92]. The products of this reaction can no longer be converted into ceramides. More recently, the free fatty acids and ceramides from the atopic stratum corneum have been compared in detail to those from the normal control stratum corneum [93]. The free fatty acids from the atopic subjects were shifted toward shorter chain lengths and contained more monounsaturated species. Likewise, the ceramides contained, on average, shorter fatty acids. When compared by ATR-FTIR, the atopic stratum corneum showed less lateral order in lipid packing compared to the control stratum corneum. Less orderly chain packing would be expected to lead to increased transepidermal water loss, as is seen in this condition. Similar observations have been made on the free fatty acids and ceramides in the stratum corneum of Netherton syndrome [94]. The skin of subjects with atopic dermatitis tends to become colonized with Staphylococcus aureus [95]. This represents a risk for infection and may reflect the fact that both free sphingosine and sapienic acid are below normal levels in atopic skin [96,97]. Both of these lipids are potent antimicrobials against $S$. aureus [98].

Psoriasis is a relatively common inflammatory skin disease that affects over 60 million people worldwide [99]. Psoriasis has several clinical presentations; however, the most common type is plaque psoriasis or psoriasis vulgaris. Psoriasis can occur at any age in either gender. Plaque psoriasis is characterized by pink plaques with silvery scales on white skin or grey plaques on black skin. The plaques are hyperproliferative and have elevated transepidermal water loss [100]. The proportions of the ceramides from the psoriatic scale are altered compared to normal with a reduction of ceramide EOS being most notable [48,101-103]. In one study, the levels of serinepalmitoyl transferase (SPT), the ratelimiting enzyme in ceramide synthesis, and ceramidase in psoriatic scale and nonlesional skin were compared [104]. The level of SPT was lower in the psoriatic scale compared to the uninvolved stratum corneum, but there was no difference in the ceramidase levels. 
Since ceramides are signaling molecules that can slow proliferation, it was suggested that the reduced ceramide level may be responsible for the hyperproliferation. The levels of free sphingosine and dihydrosphingosine were found to be higher on the psoriatic scale compared to stratum corneum from uninvolved skin. This may reflect excess longchain base synthesis rather than ceramidase action. Since the long-chain bases are potent antimicrobials this finding may help to explain the fact that psoriatics do not suffer many skin infections compared to atopics [98,105].

Mutations in several genes that catalyze steps in the biosynthesis of the corneocyte lipid envelope cause various autosomal recessive congenital ichthyoses, or ARCI [3,4]. These include ELOV1, ELOV4, CER3, PNPLA1, ABHD5, FATP4, 12R-LOX, ALOXE3, CYP4F22, SDR9C7, and TGM1. ELOV1 and ELOV4 are fatty acyl-CoA elongase genes. Mutations in these elongase genes not only result in ARCI but also result in neurologic malfunction. CER3 codes for a ceramide synthase. FATP4 codes for an enzyme that converts long-chain $\omega$-hydroxyacids to the corresponding CoA thioester. PNPLA1 codes for an enzyme that transfers the linoleate from a triglyceride or phosphoglyceride to the $\omega$ hydroxyl group of the $\omega$-hydroxyacid, and the product from $A B H D 5$ is a cofactor of the PNPLA1 product. Mutations in ABHD5 cause ARCI and Chanarin-Dorfman syndrome, a lipid storage disease [106]. The $\omega$-hydroxylation is mediated by the CYP4F22 gene product [107]. 12RLOX and eLOX3, the enzyme coded for by ALOXE3, modify the linoleate before the attachment of lipid to the cornified envelope [108]. TGM1 codes for transglutaminase 1, which is essential in the formation of the cornified envelope and may attach the $\omega$-hydroxyceramide to the outer surface of the cornified envelope to form the corneocyte lipid envelope [109]. Mutations in this gene result in lamellar ichthyosis [110]. SDR9C7 provides an alternative to transglutaminase-mediated attachment of lipid to the cornified envelope to form the CLE [111]. The importance of these genes in the biosynthesis of the CLE has been confirmed by a series of experiments using knockout mice [3].

Mutations of $A B C A 12$ result in a severe form of ARCI, Harlequin ichthyosis [112]. Newborns with Harlequin ichthyosis are covered with a thick membrane with large diamond-shaped plates. In this condition, approximately $50 \%$ mortality is seen in the perinatal period. After shedding this initial collodion membrane, the affected subjects have congenital ichthyosiform erythroderma (CIE), a red scaly skin. The gene product of $A B C A 12$ is an ATP binding cassette transporter necessary for transferring lipid into the lamellar granules that then deliver this lipid to the bottom of the stratum corneum. In Harlequin ichthyosis, the "empty" lamellar granules are seen by transmission electron microscopy, and a corneocyte lipid envelope is present [3]. However, the intercellular spaces of the stratum corneum contain only sparse lamellar material. CIE subjects have much elevated transepidermal water loss, and dehydration can be a problem.

Recessive X-linked ichthyosis (RXLI) is characterized by dry scaly skin with elevated transepidermal water loss [113]. Cholesterol sulfate was identified as a minor component of epidermal lipids in 1975 [19]. This type of ichthyosis was first recognized as being sex-linked by Wells and Kerr [114]. It was subsequently shown to be due to a sterol sulfatase deficiency [115]. In normal epidermis, cholesterol sulfate represents about 5-10\% of the polar lipid or about $2-3 \%$ of the total lipid; however, it is present in only trace amounts in exfoliated material $[116,117]$. In the stratum corneum from RXLI, cholesterol sulfate accumulates to about six times the normal concentration [118]. Cholesterol sulfate inhibits serine proteases that normally would degrade corneodesmosomes leading to desquamation [119]. This inhibition of desquamation accounts for the scaliness in RXLI. It has been suggested that excess cholesterol sulfate in the stratum corneum could induce a lamellar to a nonlamellar lipid phase transition, which could account for the defective barrier [120].

\section{Buccal Absorption}

The nonkeratinized oral regions of the oral mucosa are more permeable than the keratinized regions making the floor of the mouth and underside of the tongue and 
the buccal regions more attractive for drug delivery. In fact, for more than a century nitroglycerin has been delivered systemically to alleviate angina pain by placement under the tongue [121]. The floor of the mouth is the most permeable region of the oral mucosa, and accordingly is the most frequent site of oral squamous cell carcinoma because this is where the carcinogens can best penetrate. However, the buccal regions provide greater surface area and, therefore, have received more attention regarding drug delivery. These attempts usually involve a drug incorporated into an ointment, gel, or mucoadhesive patch. Colgate-Palmolive markets Orabase with benzocaine for pain relief. The most common oral film materials for transmucosal drug delivery include the polysaccharide polymer pullulan, maltodextrin, alginate, pectin, chitosan, and other natural polymers [122].

Many of the chemical permeation enhancers identified for skin have proven to also enhance buccal permeability $[123,124]$. These include surfactants, bile salts, fatty acids, ethanol, terpenes, and azone. Interestingly, one of the commonly used film materials, chitosan, is a permeability enhancer [124]. Chitosan is partially deacetylated chitin from shellfish. Chitin is a linear polymer of $\mathrm{N}$-acetylglucosamine in $\beta-(1 \rightarrow 4)$ linkage. At physiological $\mathrm{pH}$, chitosan is positively charged. In one study, chitosan was compared with negatively charged sulfobutyl ether- $\beta$-cyclodextrin and neutral hydroxypropyl- $\beta$-cyclodextrin as permeability enhancers for transbuccal delivery of ropinirole hydrochloride [125]. All three polymers enhanced permeability to the test drug with chitosan being the most effective hydroxypropyl- $\beta$-cyclodextrin being least effective. An FTIR study of the treated tissue indicated alteration of lipid organization with possible solubilization of the intercellular lipid. The symmetric and asymmetric methylene stretching absorbance were broadened and diminished in the area by the neutral and negatively charged polymers, but these signals completely disappeared in the tissue treated with chitosan.

The buccal drug delivery route permits the delivery of much larger molecules than skin. For transdermal delivery, the molecular weight cutoff is about 350 daltons. In a study of diffusion of fluorescein-conjugated dextrans through the porcine buccal mucosa, the molecular weight cutoff was somewhere between 10,000 and 20,000 daltons [126]. This raises the possibility of delivering peptides and nucleic acid via this route. More than thirty studies have been directed at various aspects of delivering insulin systemically by buccal absorption. A variety of methodology has been used, including various films, penetration enhancers, and incorporation of insulin into nanoparticles. One of the more unusual approaches used a conjugate of a cell-penetrating peptide (LMWP) with pegylated insulin (INS-PEG-LMWP) [127]. The uptake and transportation of INS-PEG-LMWP across buccal mucosa were much enhanced compared to insulin in solution. In a rabbit model, the insulin derivative had good bioavailability and effectively reduced circulating glucose levels. An earlier study incorporated insulin and a cell-penetrating peptide into nanoparticles which enhanced insulin delivery across a mucous secreting cell culture [128]. A mucoadhesive patch containing these nanoparticles was shown to increase serum insulin concentration and induce a hypoglycemic response in diabetic rats. Another novel approach to enhance buccal absorption of insulin involved the use of an ionic liquid as a permeability enhancer [129]. Insulin was dissolved in the ionic liquid consisting of choline and geranic acid. This eutectic liquid was sandwiched between two layers of a mixed poly-(vinyl alcohol)/chitosan film. This increased the transport of insulin across porcine buccal mucosa sevenfold. When such patches were placed in the rat buccal pouch, blood glucose levels were reduced in a dose-dependent manner with up to a 50\% drop recorded. Ionic liquids are unusually good solvents. In this case, the mechanism of action may be the extraction of lipids from the outer epithelium into a pool of ionic lipid at the mucosal surface [129].

In one innovative study, a combination of oxaliplatin-loaded chitosan nanoparticles combined with iontophoresis was tested as a possible means of treatment of tumors within the oral mucosa [130]. The mucoadhesive chitosan nanoparticles delivered an initial burst of drug followed by a longer-term steady release of the drug. The steady-state rate of drug 
penetration into porcine buccal mucosa was three times greater than that from oxaliplatin solution. This was further enhanced two-fold by iontophoresis.

Like skin, the buccal mucosa is an attractive site for immunization. One study tested the effectiveness of a microneedle array for immunization via murine buccal mucosa [131] Solid microneedles in an array were coated with ovalbumin, and the microneedle array was applied to murine buccal mucosa twice two weeks apart. A high serum IgG titer was subsequently observed, thus validating this approach [132].

Funding: There was no funding for the preparation of this manuscript.

Institutional Review Board Statement: Not applicable.

Informed Consent Statement: Not applicable.

Data Availability Statement: Not applicable.

Acknowledgments: The author would like to thank Nancy Wertz for the help in the preparation of the figures.

Conflicts of Interest: The author has no conflict of interest.

\section{References}

1. Wertz, P.W. Lipids and the permeability and antimicrobial barriers of the skin. J. Lipids 2018. [CrossRef]

2. Schmitt, T.; Neubert, R.H.H. State of the art in stratum corneum research: The biophysical properties of ceramides. Chem. Phys. Lipids 2018, 216, 91-103. [CrossRef]

3. Crumrine, D.; Khnykin, D.; Krieg, P.; Man, M.-Q.; Celli, A.; Mauro, T.M.; Wakefield, J.S.; Menon, G.; Mauldin, E.; Miner, J.H.; et al. Mutations in recessive congenital ichthoses illuminate the origin and functions of the corneocyte lipid envelope. J. Investig. Dermatol. 2019, 139, 760-768. [CrossRef] [PubMed]

4. Wertz, P.W. Lipid metabolic events underlying the formation of the corneocyte lipid envelope. Skin Pharmacol. Physiol. 2021, 34, 38-50. [PubMed]

5. Attenborough, D. Life on Earth, 1st ed.; Little Brown \& Company: Boston, MA, USA, 1980.

6. Baker, H.; Kligman, A.M. A simple in vivo method for studying the permeability of the human stratum corneum. J. Investig. Dermatol. 1967, 48, 273-274. [CrossRef]

7. Yardley, H.J. Epidermal lipids. Int. J. Cosmet. Sci. 1987, 9, 13-19. [CrossRef]

8. Diaz-Del Consuelo, I.; Jacques, Y.; Pizzolato, G.-P.; Guy, R.H.; Falson, F. Comparison of the lipid composition of porcine buccal and esophageal permeability barriers. Arch. Oral Biol. 2005, 50, 981-987. [CrossRef]

9. Pinto, S.; Pintado, M.E.; Sarmento, B. In Vivo, ex vivo and in vitro assessment of buccal permeation of drugs from delivery systems. Expert Opin. Drug Deliv. 2020, 17, 33-48. [CrossRef]

10. Scheuplein, R.J. Permeability of the skin: A review of major concepts and some new developments. J. Investig. Dermatol. 1976, 67, 672-676. [CrossRef]

11. Manganaro, A.M. Review of transmucosal drug delivery. Militar. Med. 1997, 162, 27-30. [CrossRef]

12. Nemanic, M.K.; Elias, P.M. In Situ precipitation: A novel cytochemical technique for visualization of permeability pathways in mammalian stratum corneum. J. Histochem. Cytochem. 1980, 28, 573-578. [CrossRef]

13. Squier, C.A.; Lesch, C.A. Penetration pathways of different compounds through epidermis and oral epithelia. J. Oral Pathol. 1988, 17, 512-516. [CrossRef]

14. Patzelt, A.; Lademann, J. Drug delivery to hair follicles. Expert Opin. Drug Deliv. 2013, 10, 787-797. [CrossRef]

15. Gorsky, M.; Buchner, A.; Fundoianu-Dayan, D.; Cohen, C. Fordyce's granules in the oral mucosa of adult Israeli Jews. Commun. Dent. Oral Epidemiol. 1986, 14, 231-232. [CrossRef]

16. Olivier, J.H. Fordyce granules on the prolabial and oral mucous membranes of a selected population. S. Afr. Dent. J. 2006, $61,72-74$.

17. Nicolaides, N. Skin Lipids. II. Lipid class composition of samples from various species and anatomical locations. J. Am. Oil Chem. Soc. 1965, 42, 691-702. [CrossRef]

18. Gray, G.M.; White, R.J. Glycosphingolipids and ceramides in human and pig epidermis. J. Investig. Dermatol. 1978, 70, 336-341. [CrossRef]

19. Gray, G.M.; Yardley, H.J. Different populations of pig epidermal cells: Isolation and lipid composition. J. Lipid Res. 1975, 16, 441-447. [CrossRef]

20. Wertz, P.W.; Swartzendruber, D.C.; Madison, K.C.; Downing, D.T. Composition and morphology of epidermal cyst lipids. J. Investig. Dermatol. 1987, 89, 419-424. [CrossRef]

21. Gray, G.M.; White, R.J.; Majer, J.R. 1-(3'-)-acyl-beta-glucosyl-N-dihydropentatriacontadienoyl-sphingosine of pig and human epidermis. Biochim. Biophys. Acta 1978, 528, 127-137. [CrossRef] 
22. Wertz, P.W.; Downing, D.T. Acylglucosylceramides of pig epidermis: Structure determination. J. Lipid Res. 1983, $24,753-758$. [CrossRef]

23. Abraham, W.; Wertz, P.W.; Downing, D.T. Linoleate-rich acylglucosylceramides of pig epidermis: Structure determination by proton magnetic resonance. J. Lipid Res. 1985, 26, 761-766. [CrossRef]

24. Bowser, P.A.; Nugteren, D.H.; White, R.J.; Houtsmuller, U.M.; Prottey, C. Identification, isolation and characterization of epidermal lipids containing linoleic acid. Biochim. Biophys. Acta 1985, 843, 419-428. [CrossRef]

25. Wertz, P.W.; Downing, D.T. Glucosylceramides of pig epidermis: Structure determination. J. Lipid Res. 1983, $24,1135-1139$. [CrossRef]

26. Wertz, P.W.; Downing, D.T. Ceramides of pig epidermis: Structure determination. J. Lipid Res. 1983, 24, 759-765. [CrossRef]

27. Wertz, P.W.; Downing, D.T.; Freinkel, R.K.; Traczyk, T.N. Sphingolipids of the stratum corneum and lamellar granules of fetal rat epidermis. J. Investig. Dermatol. 1984, 83, 193-195. [CrossRef] [PubMed]

28. Grayson, S.; Johnson-Winegar, A.G.; Wintraub, B.U.; Isseroff, R.R.; Epstein, E.H.; Elias, P.M. Lamellar body-enriched fractions from neonatal mice: Preparative techniques and partial characterization. J. Investig. Dermatol. 1985, 85, 289-294. [CrossRef]

29. Wertz, P.W.; Downing, D.T. Covalently bound omega-hydroxyacylsphingosine in the stratum corneum. Biochim. Biophys. Acta 1987, 917, 108-111. [CrossRef]

30. Swartzendruber, D.C.; Wertz, P.W.; Madison, K.C.; Downing, D.T. Evidence that the corneocyte has a chemically bound lipid envelope. J. Investig. Dermatol. 1987, 88, 709-713. [CrossRef]

31. Madison, K.C.; Swartzendruber, D.C.; Wertz, P.W.; Downing, D.T. Presence of intact intercellular lipid lamellae in the upper layers of the stratum corneum. J. Investig. Dermatol. 1987, 88, 714-718. [CrossRef] [PubMed]

32. Bouwstra, J.A.; Gooris, G.S.; van der Spek, J.A.; Bras, W. Structural investigations of human stratum corneum by small-angle X-ray scattering. J. Investig. Dermatol. 1991, 97, 1005-1012. [CrossRef] [PubMed]

33. Bouwstra, J.A.; Gooris, G.S.; Dubbelaar, F.E.; Weerheim, A.M.; Izerman, A.P.; Ponec, M. Role of ceramide 1 in the organization of the stratum corneum lipids. J. Lipid Res. 1998, 39, 186-196. [CrossRef]

34. Kuempel, D.; Swartzendruber, D.C.; Squier, C.A.; Wertz, P.W. In Vitro reconstitution of stratum corneum lipid lamellae. Biochim. Biophys. Acta 1998, 1372, 135-140. [CrossRef]

35. Bouwstra, J.A.; Gooris, G.S.; van der Spek, J.A.; Lavrijsen, S.; Bras, W. The lipid and protein structure of mouse stratum corneum: A wide and small angle diffraction study. Biochim. Biophys. Acta 1994, 1212, 183-192. [CrossRef]

36. Pilgram, G.S.; Engeksma-van Pelt, A.M.; Bouwstra, J.A.; Koerten, H.K. Electron diffraction provides new information on human stratum corneum lipid organization studied in relation to depth and temperature. J. Investig. Dermatol. 1999, 113, 403-409. [CrossRef]

37. Bouwstra, J.A.; Pilgram, G.S.; Gooris, G.S.; Koerten, H.K.; Ponec, M. New aspects of the skin barrier organization. Skin Pharmacol. Physiol. 2001, 14 (Suppl. 1), 52-62. [CrossRef]

38. Groen, D.; Poole, D.S.; Gooris, G.S.; Bouwstra, J.A. Is an orthorhombic lateral packing and a proper lateral organization important for the skin barrier function? Biochim. Biophys. Acta 2011, 1808, 1529-1537. [CrossRef]

39. Pilgram, G.S.; Vissers, D.C.; van der Meulen, H.; Pavel, S.; Larvijsen, S.P.; Bouwstra, J.A.; Koerten, H.K. Aberrant lipid organization in stratum corneum of patients with atopic dermatitis and lamellar ichthyosis. J. Investig. Dermatol. 2001, 117, 710-717. [CrossRef]

40. Elias, P.M.; Cullander, C.; Mauro, T.; Rassner, U.; Komuves, L.; Brown, B.E.; Menon, G.K. The secretary granular cell: The outermost granular cell as a specialized secretory cell. J. Investig. Dermatol. Symp. Proc. 1998, 3, 87-100. [CrossRef] [PubMed]

41. Matoltsy, A.G. Keratinization. J. Investig. Dermatol. 1976, 67, 20-25. [CrossRef] [PubMed]

42. Uchida, Y.; Hara, M.; Nishio, H.; Sidransky, E.; Inoue, S.; Otsuka, F.; Suzuki, A.; Elias, P.M.; Holleran, W.M. Epidermal sphingomyelins are precursors for selected stratum corneum ceramides. J. Lipid Res. 2000, 41, 2071-2082. [CrossRef]

43. Hamanaka, S.; Hara, M.; Nishio, H.; Otsuka, F.; Suzuki, A.; Uchida, Y. Human epidermal glucosylceramides are major precursors of stratum corneum ceramides. J. Investig. Dermatol. 2002, 119, 416-423. [CrossRef]

44. Mao-Qiang, M.; Feingold, K.R.; Jain, M.; Elias, P.M. Extracellular processing of phospholipids is required for permeability barrier homeostasis. J. Lipid Res. 1995, 36, 1925-1935. [CrossRef]

45. Ilic, D.; Bollinger, J.M.; Gelb, M.; Mauro, T.M. sPLA 2 and the epidermal barrier. Biochim. Biophys. Acta 2014, $1841,416-421$. [CrossRef]

46. Landmann, L. Epidermal permeability barrier: Transformation of lamellar granule-disks into intercellular sheets by a membranefusion process, a freeze-fracture study. J. Investig. Dermatol. 1986, 87, 202-209. [CrossRef]

47. Ponec, M.; Weerheim, A.; Lankhorst, P.; Wertz, P. New acylceramide in native and reconstructed epidermis. J. Investig. Dermatol. 1989, 92, 581-588. [CrossRef]

48. Motta, S.; Monti, M.; Sesana, S.; Caputo, R.; Carelli, S.; Ghidoni, R. Ceramide composition of the psoriatic scale. Biochim. Biophys. Acta Mol. Basis Dis. 1993, 1182, 147-151. [CrossRef]

49. Squier, C.A.; Kremer, M.J. Biology of oral mucosa and esophagus. J. Nat. Cancer Instit. Monogr 2001, 29, 7-15. [CrossRef]

50. Hayward, A.F.; Hackemann, M. Electron microscopy of membrane-coating granules and a cell surface coat in keratinized and nonkeratinized human oral epithelium. J. Ultrastruc. Res. 1973, 43, 205-219. [CrossRef]

51. Squier, C.A. Zinc iodide-osmium staining of membrane-coating granules in keratinized and non-keratinized mammalian oral epithelium. Arch. Oral Biol. 1982, 27, 377-382. [CrossRef]

52. Schroeder, H.E. Differentiation of Human Oral Stratified Epithelia, 1st ed.; Karger: Basel, Switzerland, 1981. 
53. Law, S.; Wertz, P.W.; Swartzendruber, D.C.; Squier, C.A. Regional variation in content, composition and organization of porcine epithelial barrier lipids revealed by thin-layer chromatography and transmission electron microscopy. Arch. Oral Biol. 1995, 40, 1085-1091. [CrossRef]

54. Hill, J.R.; Wertz, P.W. Structures of the ceramides from porcine palatal stratum corneum. Lipids 2009, 44, 291-295. [CrossRef] [PubMed]

55. Groen, D.; Gooris, G.S.; Bouwstra, J.A. Model membranes prepared with ceramide EOS, cholesterol and free fatty acids form a unique lamellar phase. Langmuir 2010, 26, 4168-4175. [CrossRef]

56. Mojumdar, E.H.; Gooris, G.S.; Groen, D.; Barlow, D.J.; Lawrence, M.J.; Deme, B.; Bouwstra, J.A. Stratum corneum lipid matrix: Localization of ceramide and cholesterol in the unit cell of the long periodicity phase. Biochim. Biophys. Acta 2016, 1858, 1926-1936. [CrossRef]

57. Swartzendruber, D.C.; Manganaro, A.; Madison, K.C.; Kremer, M.; Wertz, P.W.; Squier, C.A. Organization of the intercellular spaces of porcine epidermal and palatal stratum corneum: A quantitative study employing ruthenium tetroxide. Cell Tissue Res. 1995, 279, 271-276. [CrossRef]

58. Chang, F.; Swartzendruber, D.C.; Wertz, P.W.; Squier, C.A. Covalently bound lipids in keratinizing epithelia. Biochim. Biophys. Acta 1993, 1150, 98-102. [CrossRef]

59. Lesch, C.A.; Squier, C.A.; Cruchley, A.; Williams, D.M.; Speight, P. The permeability of human oral mucosa and skin to water. J. Dent. Res. 1989, 68, 1345-1349. [CrossRef]

60. Squier, C.A.; Hall, B.K. The permeability of skin and oral mucosa to water and horseradish peroxidase as related to the thickness of the permeability barrier. J. Investig. Dermatol. 1985, 84, 176-179. [CrossRef]

61. Squier, C.A. The permeability of keratinized and nonkeratinized oral epithelium to horseradish peroxidase. J. Ultrastruc. Res. 1973, 43, 160-177. [CrossRef]

62. Squier, C.A.; Rooney, L. The permeability of keratinized and nonkeratinized oral epithelium to lanthanum in vivo. J. Ultrastruc. Res. 1976, 54, 286-295. [CrossRef]

63. Squier, C.A. Membrane coating granules in nonkeratinizing epithelium. J. Ultrastruc. Res. 1977, 60, 212-220. [CrossRef]

64. Potts, R.O.; Guy, R.H. Predicting skin permeability. Pharm. Res. 1992, 9, 663-669. [CrossRef]

65. Kovacik, A.; Kopecna, M.; Vavrova, K. Permeation enhancers in transdermal drug delivery: Benefits and limitations. Expert. Opin. Drug Deliv. 2020, 17, 145-155. [CrossRef]

66. Uchida, N.; Yanagi, M.; Hamada, H. Physical enhancement? Nanocarrier? Current progress in transdermal drug delivery. Nanomaterials 2021, 11, 335. [CrossRef]

67. Schoellhammer, C.M.; Blankschstein, D.; Langer, R. Skin permeabilization for transdermal drug delivery: Recent advances and future prospects. Expert. Opin. Drug Deliv. 2014, 11, 393-407. [CrossRef]

68. Daftardar, S.; Bahl, D.; Boddu, S.H.S.; Altorok, N.; Kahaleh, B. Ultrasound-mediated topical delivery of econazole nitrate with potential for treating Raynaud's phenomenon. Int. J. Pharm. 2020, 580, 119229. [CrossRef] [PubMed]

69. Vaidya, J.; Shende, P. Potential of sonophoresis as a skin penetration technique in the treatment of rheumatoid arthritis with transdermal patch. AAPS PharmSciTech 2020, 21, 180. [CrossRef]

70. Mitragoti, S.; Blankschstein, D.; Langer, R. Ultrasound-mediated transdermal protein delivery. Science 1995, $269,850-853$. [CrossRef] [PubMed]

71. Wang, Y.; Zeng, L.; Song, W.; Liu, J. Influencing factors and drug application of iontophoresis in transdermal drug delivery: An overview of recent progress. Drug Deliv. Transl. Res. 2021. [CrossRef] [PubMed]

72. Tierney, M.J.; Tamada, J.A.; Potts, R.O.; Eastman, R.C.; Pitzer, K.; Ackerman, N.R.; Fermi, S.J. The GlucoWatch biographer: A frequent automatic and noninvasive glucose monitor. Ann. Med. 2000, 32, 632-641. [CrossRef] [PubMed]

73. Sieg, A.; Guy, R.H.; Delgado-Charro, M.B. Noninvasive and minimally invasive methods for transdermal glucose monitoring. Diabetes Ther. 2005, 7, 174-197. [CrossRef]

74. Giri, T.K.; Chakrabarty, S.; Ghosh, B. Transdermal reverse iontophoresis: A novel technique for therapeutic drug monitoring. J. Control. Release 2017, 28, 230-246. [CrossRef]

75. Nawrocki, S.; Cha, J. The etiology, diagnosis, and management of hyperhydrosis: A comprehensive review: Therapeutic options. J. Am. Acad. Dermatol. 2019, 81, 669-680. [CrossRef] [PubMed]

76. Dermol-Cerne, J.; Pirc, E.; Miklavcic, D. Mechanistic view of skin electroporation-models and dosimetry for successful applications: An expert review. Expert. Opin. Drug Deliv. 2020, 17, 689-704. [CrossRef]

77. Campana, L.G.; Miklavcic, D.; Bertino, G.; Marcanato, R.; Valpione, S.; Imarisio, I.; Dieci, M.V.; Granziera, E.; Cemazar, M.; Alaibac, M.; et al. Electrochemotherapy of superficial tumors-Current status: Basic principles, operating procedures, shared indications, and emerging applications. Semin. Oncol. 2019, 46, 173-191. [CrossRef] [PubMed]

78. Yang, D.; Chen, M.; Sun, Y.; Jin, Y.; Lu, C.; Pan, X.; Quan, G.; Wu, C. Microneedle-mediated transdermal drug delivery for treating diverse skin diseases. Acta. Biomater. 2021, 121, 119-133. [CrossRef]

79. Halder, J.; Gupta, S.; Kumari, R.; Das Gupta, G.; Rai, V.K. Microneedle array: Applications, Recent Advances, and Clinical Pertinence in Transdermal Drug Delivery. J. Pharm. Innov. 2020, 8, 1-8.

80. Dabholkar, N.; Gorantla, S.; Waghule, T.; Rapalli, V.K.; Kothuru, A.; Goel, S.; Singvi, G. Biodegradable microneedles with carbohydrates and proteins: Revolutionary approach for transdermal drug delivery. Int. J. Biol. Macromol. 2021, 170, 621-802. [CrossRef] [PubMed] 
81. Elahpour, N.; Pahlevanzadeh, F.; Kharaziha, M.; Bakhsheshi-Rad, H.; Ramakrishna, S.; Berto, F. 3D printed microneedles for transdermal drug delivery: A brief review of two decades. Int. J. Pharm. 2021. [CrossRef] [PubMed]

82. D'Amico, C.; Fontana, F.; Cheng, R.; Santos, H.A. Development of vaccine formulations: Past, present, and future. Drug Deliv. Transl. Res. 2021, 11, 353-372. [CrossRef]

83. Korkmaz, E.; Balmert, S.C.; Sumpter, T.L.; Carey, C.D.; Erdos, G.; Falo, L.D. Microarray patches enable the development of skin-targeted vaccines against COVID-19. Adv. Drug Deliv. Rev. 2021, 171, 164-186. [CrossRef] [PubMed]

84. Koutsonanos, D.G.; Esser, E.S.; McMaster, S.R.; Kalluri, P.; Lee, J.-W.; Prausnitz, M.R.; Skountzou, I.; Denning, T.L.; Kohlmeier, J.E.; Compans, R.W. Enhanced immune responses by skin vaccination with influenza subunit vaccine in young hosts. Vaccine 2015, 33, 4675-4682. [CrossRef]

85. Epstein, W.L. Occupational poison ivy and oak dermatitis. Dermatol. Clin. 1994, 12, 511-516. [CrossRef]

86. Kim, Y.; Flamm, A.; ElSohly, M.A.; Kaplan, D.H.; Hage, R.J.; Hamann, C.P.; Marks, J.G. Poison Ivy, Oak and Sumac dermatitis: What is known and what is new? Dermatitis 2019, 30, 183-190. [CrossRef] [PubMed]

87. Berardesca, E.; Maibach, H.I. Transepidermal water loss and skin surface hydration in the non invasive assessment of stratum corneum. Derm. Beruf. Unwelt 1990, 38, 50-53.

88. Melnik, B.; Hollmann, J.; Hofmann, U.; Yub, M.S.; Plewig, G. Lipid composition of outer stratum corneum and nails in atopic and control subjects. Arch. Dermatol. Res. 1990, 282, 549-551. [CrossRef]

89. Yamamoto, A.; Serizawa, S.; Ito, M.; Sato, Y. Stratum corneum lipid abnormalities in atopic dermatitis. Arch. Dermatol. Res. 1991, 283, 219-223. [CrossRef]

90. Imokawa, G.; Abe, A.; Jin, K.; Higaki, Y.; Kawashima, M.; Hidano, A. Decreased level of ceramides in stratum corneum of atopic dermatitis: An etiologic factor in atopic dry skin? J. Investig. Dermatol. 1991, 96, 523-526. [CrossRef] [PubMed]

91. Di Nardo, A.; Wertz, P.; Gianetti, A.; Seidenari, S. Ceramide and cholesterol composition of the skin of patients with atopic dermatitis. Acta Derm. Venereol. 1998, 78, 27-30. [CrossRef] [PubMed]

92. Imokawa, G. Cutting edge of the pathogenesis of atopic dermatitis: Sphingomyelin deacylase, the enzyme involved in its ceramide deficiency, plays a pivotal role. Int. J. Mol. Sci. 2021, 22, 1613. [CrossRef]

93. Van Smeden, J.; Janssens, M.; Kaye, E.C.J.; Caspers, P.J.; Lavrijsen, A.P.; Vreeken, R.J.; Bouwstra, J.A. The importance of free fatty acid chain length for the skin barrier function in atopic eczema patients. Exp. Dermatol. 2014, 23, 45-52. [CrossRef]

94. Van Smeden, J.; Janssens, M.; Boiten, W.A.; van Drongelen, V.; Furio, L.; Vreeken, R.J.; Hovnanian, A.; Bouwstra, J.A. Intercellular skin barrier lipid composition and organization in Netherton syndrome patients. J. Investig. Dermatol. 2014, 134, 1238-1245. [CrossRef]

95. Edsley, S.M.; Olesen, C.M.; Norreslet, L.B.; Ingham, A.C.; Iversen, S.; Lilje, B.; Clausen, M.L.; Jensen, J.S.; Stegger, M.; Agner, T.; et al. Staphylococcal communities on skin associated with atopic dermatitis and disease severity. Microorganisms 2021, 9, 432. [CrossRef]

96. Arikawa, J.; Ishibashi, M.; Kawashima, M.; Tagaki, Y.; Ichikawa, Y.; Imokawa, G. Decreased levels of sphingosine, a natural antimicrobial agent, may be associated with vulnerability of the stratum corneum from patients with atopic dermatitis to colonization by Staphylococcus aureus. J. Investig. Dermatol. 2002, 119, 433-439. [CrossRef] [PubMed]

97. Takigawa, H.; Nakagawa, H.; Kuzukawa, M.; Mori, H.; Imokawa, G. Deficient production of hexadecanoic acid in the skin is associated in part with the vulnerability of atopic dermatitis patients to colonization by Staphylococcus aureus. Dermatology 2005, 211, 240-248. [CrossRef]

98. Fischer, C.L.; Drake, D.R.; Dawson, D.V.; Blanchette, D.R.; Brogden, K.A.; Wertz, P.W. Antibacterial activity of sphingoid bases and fatty acids against Gram-positive and Gram-negative bacteria. Antimicrob. Agents Chemother. 2012, 56, 1157-1161. [CrossRef] [PubMed]

99. Griffiths, C.E.M.; Armstrong, A.W.; Dudjonsson, J.E.; Barker, J.N.W.N. Psoriasis. Lancet 2021, 397, 1301-1315. [CrossRef]

100. Montero-Vilchez, T.; Segura-Fernandez-Hogueras, M.-V.; Perez-Rodriguez, I.; Soler-Gongora, M.; Martinez-Lopez, A.; FernandezGonzalez, A.; Molina-Leyva, A.; Arias-Santiago, S. Skin barrier function in psoriasis and atopic dermatitis: Transepidermal water loss and temperature as useful tooks to assess disease severity. J. Clin. Med. 2021, 10, 359. [CrossRef] [PubMed]

101. Motta, S.; Monti, M.; Sesana, S.; Mellesi, L.; Ghidoni, R.; Caputo, R. Abnormality of water barrier function in psoriasis. Role of ceramide fractions. Arch. Dermatol. 1994, 130, 452-456. [CrossRef] [PubMed]

102. Motta, S.; Sesani, S.; Ghidoni, R.; Monti, M. Content of the different lipid classes in psoriatic scale. Arch. Dermatol. Res. 1995, 287, 691-694. [CrossRef] [PubMed]

103. Lew, B.-L.; Cho, Y.; Kim, J.; Sim, W.-Y.; Kim, N.-I. Ceramides and signaling molecules in psoriatic epidermis: Reduced levels of ceramides, PKC- $\alpha$, and JNK. J. Korean Med. Sci. 2006, 21, 95-99. [CrossRef]

104. Hong, K.-K.; Cho, H.-R.; Ju, W.-C.; Cho, Y.; Kim, N.-I. A study on altered expression of serinepalmitoyl transferase (SPT) and ceramidase in psoriatic skin lesion. J. Korean Med. Sci. 2007, 22, 862-867. [CrossRef] [PubMed]

105. Kiatsurayanon, C.; Ogawa, H.; Niyonsaba, F. The role of host defense peptide human $\beta$-defensin in the maintenance of the skin barriers. Curr. Pharmaceut. Des. 2018, 24, 1092-1099. [CrossRef] [PubMed]

106. Demerjian, M.; Crumrine, D.A.; Milstone, L.M.; Williams, M.L.; Elias, P.M. Barrier disfunction and pathogenesis of neutral lipid storage disease with ichthyosis (Chanarin-Dorfman syndrome). J. Investig. Dermatol. 2006, 126, 2032-2038. [CrossRef] 
107. Ohno, Y.; Nakamichi, S.; Ohkuni, A.; Kamiyama, N.; Naoe, A.; Tsujimura, H.; Yokose, U.; Sugiura, K.; Ishikawa, J.; Akiyama, M.; et al. Essential role of the cytochrome P450 CYP4F22 in the production of acylceramide, the key lipid for skin permeability barrier formatuion. Proc. Natl. Acad. Sci. USA 2015, 112, 7707-7712. [CrossRef]

108. Zheng, Y.; Yin, H.; Boeglin, W.E.; Elias, P.M.; Crumrine, D.; Beier, D.R.; Brash, A.R. Lipoxygenases mediate the effect of essential fatty acid in skinj barrier formation: A proposed role in releasing 0mega-hydroxyceramide for construction of the corneocyte lipid envelope. J. Biol. Chem. 2011, 286, 4046-4056. [CrossRef] [PubMed]

109. Nemes, Z.; Marekov, L.N.; Festis, L.; Steinert, P.M. A novel function for transglutaminase 1: Attachment of omegahydroxyceramide to involucrin by ester bond formation. Proc. Nat. Acad. Sci. USA 1999, 96, 8402-8407. [CrossRef]

110. Russel, L.J.; DiGiovanna, J.J.; Rogers, G.R.; Steinert, P.M.; Hashem, N.; Compton, J.G.; Bale, S.J. Mutations in the gene for transglutaminase 1 in autosomal recessive lamellar ichthyosis. Nat. Genet. 1995, 9, 279-283. [CrossRef] [PubMed]

111. Takeichi, T. SDR9C7 plays an essential role in skin barrier function by dehydrogenating acylceramide for attachment to proteins. J. Dermatol. Sci. 2020, 98, 82-87. [CrossRef] [PubMed]

112. Shibata, A.; Akayama, M. Epidemiology, medical genetics, diagnosis and treatment of harlequin ichthyosis in Japan. Pediatr. Int. 2015, 57, 516-522. [CrossRef]

113. Elias, P.M.; Williams, M.L.; Holleran, W.M.; Jiang, Y.J.; Schmuth, M. Pathogenesis of permeability barrier abnormalities in the ichthyoses: Inherited disorders of lipid metabolism. J. Lipid Res. 2008, 49, 697-714. [CrossRef]

114. Wells, R.S.; Kerr, C.B. Genetic classification of ichthyosis. Arch. Dermatol. 1965, 92, 1-6. [CrossRef] [PubMed]

115. Shapiro, L.J.; Weiss, R.; Webster, D.; France, J.T. X-linked ichthyosis due to steroid sulfatase deficiency. Lancet 1978, 1, 70-72. [CrossRef]

116. Long, S.A.; Wertz, P.W.; Strauss, J.S.; Downing, D.T. Human stratum corneum polar lipids and desquamation. Arch. Dermatol. Res. 1985, 277, 484-487. [CrossRef] [PubMed]

117. Ranasingh, A.W.; Wertz, P.W.; Downing, D.T.; Mackenzie, I.C. Lipid composition of cohesive and desquamated corneocytes from mouse ear skin. J. Investig. Dermatol. 1986, 86, 187-190. [CrossRef] [PubMed]

118. Williams, M.L.; Elias, P.M. Stratum corneum lipids in disorders of cornification. J. Clin. Investig. 1981, 68, 1404-1410. [CrossRef] [PubMed]

119. Sato, J.; Denda, M.; Nakanishi, J.; Nomura, J.; Koyama, J. Cholesterol sulfate inhibits proteases that are involved in desquamation of stratum corneum. J. Investig. Dermatol. 1998, 111, 189-193. [CrossRef]

120. Elias, P.M.; Crumrine, D.; Rassner, U.; Hachem, J.-P.; Menon, G.K.; Man, W.; Choy, M.H.W.; Leypoldt, L.; Feingold, K.R.; Williams, M.L. Basis for abnormal desquamation and permeability barrier disfunction in RXLI. J. Investig. Dermatol. 2004, 122, 314-319. [CrossRef] [PubMed]

121. Wertz, P.W.; Squier, C.A. Cellular and molecular basis of barrier function in oral epithelium. Crit. Rev. Therap. Drug Carr. Syst. 1991, 8, 237-269.

122. Pacheco, M.S.; Barbieri, D.; da Silva, C.F.; de Morares, M.A. A review on orally disintegrating films (ODFs) made from natural polymers such as pullulan, maltodextrin, starch, and others. Int. J. Biol. Macromol. 2021, 178, 504-513. [CrossRef]

123. Nicolazzo, J.A.; Reed, B.L.; Finnin, B.C. Buccal permeation enhancers-How do they really work? J. Control. Release 2005, 105, 1-15. [CrossRef]

124. Sanz, R.; Calpena, A.C.; Mallandrich, M.; Clares, B. Enhancing topical analgesic administration: Review and prospect for transdermal and transbuccal drug delivery systems. Curr. Pharmaceut. Des. 2015, 21, 2867-2882. [CrossRef] [PubMed]

125. Senel, S.; Hincal, A.A. Drug permeation enhancement via buccal route: Possibilities and limitations. J. Control. Release 2001, 72, 133-144. [CrossRef]

126. Kontogiannidou, E.; Andreadis, D.A.; Zografos, A.L.; Nazar, H.; Klepetsanis, P.; van der Merwe, S.M.; Fatouros, D.G. Ex vivo drug delivery of ropinirole hydrochloride in the presence of permeation enhancers: The effect of charge. Pharm. Develop. Technol. 2017, 22, 1017-1021. [CrossRef] [PubMed]

127. Junginger, H.E.; Hoogstraate, J.A.; Verhoef, J.C. Recent advances in buccal drug delivery and absorption-in vitro and in vivo studies. J. Control. Release 1999, 62, 149-159. [CrossRef]

128. Xu, Y.; Zhang, X.; Wang, N.; Pei, X.; Guo, Y.; Wang, J.; Barth, S.; Yu, F.; Lee, S.J.; He, H.; et al. Cell-penetrating peptide enhanced insulin buccal absorption. Int. J. Pharm. 2020. [CrossRef]

129. Vaidya, A.; Mitragoti, S. Ionic liquid-mediated delivery of insulin to buccal mucosa. J. Control. Release 2020, 327, 26-34. [CrossRef]

130. Huang, W.; Wu, X.; Qi, J.; Zhu, Q.; Wu, W.; Lu, Y.; Chen, Z. Ionic liquids: Green and tailor-made solvents in drug delivery. Drug Discov. Today 2020, 25, 901-908. [CrossRef]

131. Matos, B.N.; Pereira, M.N.; de Oliveira Bravo, M.; Cunha-Filho, M.; Saldanha-Araujo, F.; Gratieri, T.; Gelfuso, G.M. Chitosan nanoparticles loaded with oxaliplatin as a mucoadhesive topical treatment of oral tumors: Iontophoresis further enhances drug delivery ex vivo. Int. J. Biol. Macromol. 2020, 154, 1265-1275. [CrossRef] [PubMed]

132. Oh, Y.-J.; Cha, H.-R.; Hwang, S.J.; Kim, D.-S.; Choi, Y.-J.; Kim, Y.-S.; Shin, Y.-R.; Nguyen, T.T.; Choi, S.-O.; Lee, J.M.; et al. Ovalbumin and cholera toxin delivery to buccal mucosa for immunization using microneedles and comparison of immunological response to transmucosal delivery. Drug. Deliv. Transl. Res. 2021. [CrossRef] [PubMed] 